\title{
Alat Bantu Pelayanan Informasi Komponen-Komponen AC Mobil untuk Konsumen Dengan Memanfaatkan Teknologi Augmented Reality Marker (Studi Kasus : Lazio Ac Mobil)
}

\author{
Fuad Nasher ${ }^{1}$, Raka Permana ${ }^{2}$ \\ ${ }^{1.2}$ Jurusan Teknik Informatika \\ Fakultas Teknik Universitas Suryakancana \\ fuad.nasher@gmai.com ${ }^{1}$,ratusyaqinah20@gmail.com ${ }^{2}$
}

\begin{abstract}
Abstrak
Perusahaan lazio AC mobil adalah perusahaan yang bergerak dibidang layanan peyediaan spare part AC mobil, dan layanan perbaikan AC mobil. Pada saat ini proses pelayanan informasi masih statis (hanya diketahui oleh mekanik). Informasi secara detail tentang komponen AC tersebut tidak diberikan secara rinci kepada konsumen, seperti mengenai fungsi dari komponen tersebut, harga, serta estimasi perbaikan pun masih sangat minim diberikan pada konsumen sehingga banyak konsumen yang mengeluh jika mereka tidak mendapatkan kepuasan dari segi pelayanan informasi tersebut. Penelitian ini dibuat untuk merancang dan membangun sebuah aplikasi menggunakan teknologi augmented reality dengan metode marker yang diharapkan dapat membantu memberikan pelayanan informasi mengenai komponen AC mobil kepada konsumen. Aplikasi Augmented Reality Komponen AC Mobil adalah aplikasi yang dibuat untuk mempermudah konsumen mendapatkan pelayanan informasi mengenai komponen AC Mobil berbasis android yang menampilkan gambar komponen dalam bentuk 3D beserta animasinya.
\end{abstract}

Kata kunci: Android, augmented reality, AC Mobil.

\section{Pendahuluan}

Augmented Reality (AR) adalah penggabungan antara objek virtual dengan objek nyata. Sebagai contoh, adalah saat stasiun televisi, menyiarkan pertandingan sepak bola, terdapat objek virtual, yang terdapat tentang skor pertandingan sepak bola yang sedang berlangsung.

Augmented Reality adalah menggabungkan dunia nyata daan virtual, bersifat interaktif secara real time, dan merupakan animasi 3D.

Perusahaan lazio AC mobil adalah sebuah perusahaan yang bergerak dibidang layanan peyediaan spare part AC mobil, dan layanan perbaikan AC mobil. Pelayanan penyampaian informasi mengenai komponen AC mobil diperusahaan ini masih terbilang minim. Penyampaian secara detail tentang komponen AC tersebut tidak diberikan secara rinci kepada konsumen, misalnya informasi mengenai fungsi dari komponen tersebut, harga, serta estimasi perbaikan pun masih sangat minim diberikan pada konsumen sehingga banyak konsumen yang mengeluh jika mereka tidak mendapatkan kepuasan dari segi pelayanan informasi tersebut. Selain itu perusahaan bengkel ini juga tidak menyediakan informasi dalam bentuk visual misalnya gambar-gambar poster komponen AC mobil yang bisa membantu konsumen dalam mendapatkan informasi mengenai komponen AC mobil itu sendiri. Sehingga mengakibatkan konsumen yang datang ke perusahaan ini mengalami penurunan untuk melakukan service dan pembelian spare part, konsumen dirugikan oleh spesifikasi spare part dan segi biaya karena tidak mengetahui dari beberapa permasalahan yang ada, seiring berkembangnya teknologi saat ini untuk mempermudah menyampaikan informasi yaitu dengan membuat aplikasi komponen AC mobil bagi konsumen. Yang memanfaatkan teknologi augmented reality. karena informasi yang di berikan tidak hanya berbentuk gambar, tetapi juga animasi dari cara kerja komponen AC mobil tersebut, deskripsi komponen, estimasi pengerjaan serta harga komponen tersebut.

Berdasarkan dari permasalahan yang terjadi maka solusi dari perkembangan yang dapat memanfaatkan teknologi yang telah ada yaitu membuat aplikasi pelayanan informasi komponen AC mobil menggunakan teknologi augmented reality marker. Aplikasi akan mempermudah penyampaian informasi pada konsumen, karena aplikasi memberikan visualisasi dalam bentuk virtual animasi 3D dan memperlihatkan bagaimana cara melayani informasi tentang komponen AC mobil dan memberikan keterangan fungsi komponen dan estimasi harga dan waktu dari pembongkaran komponen tersebut dan dapat menjelaskan isi dari dalam komponennya melalui aplikasi Augmented Reality.

Dengan adanya penerapan teknologi augmented reality sebagai aplikasi informasi komponen AC mobil diharapkan dapat membantu informasi untuk konsumen dari mekanik agar mudah dipahami, dengan menampilkan animasi objek 3D, dan Aplikasi yang dirancang ditujukan untuk aplikasi berbasis android. 


\section{Landasan Teori}

\subsection{Augmented Reality}

Augmented Reality (AR) adalah sebuah istilah untuk lingkungan yang menggabungkan dunia nyata dan dunia virtual yang dibuat oleh komputer sehingga batas antara keduanya menjadi sangat tipis. Sistem ini lebih dekat kepada lingkungan nyata "real", karena itu, reality lebih diutamakan pada sistem

Augmented Reality adalah sebuah teknik yang menggabungkan benda maya dua dimensi maupun 3 dimensi ke dalam sebuah lingkup nyata tiga dimensi lalu memproyeksikan benda- benda maya tersebut dalam waktu nyata.

Marker merupakan sebuah penanda khusus yang memiliki pola tertentu sehingga saat kamera mendeteksi marker, objek 3 dimensi dapat ditampilkan. Augmented reality saat ini melakukan perkembangan besarbesaran, salah satunya pada bagian Marker, perkembangan terbaru marker ini merupakan salah satu metode Augmented Reality tanpa menggunakan frame marker sebagai obyek yang dideteksi. Biasanya merupakan ilustrasi hitam dan putih persegi dengan batas hitam tebal dan latar belakang putih. Komputer akan mengenali posisi dan orientasi marker dan menciptakan dunia virtual

3D yaitu titik $(0,0,0)$ dan tiga sumbu yaitu $\mathrm{X}, \mathrm{Y}$, dan $\mathrm{Z}$. Marker Based Tracking ini sudah lama dikembangkan sejak 1980-an dan pada awal

1990-an mulai dikembangkan untuk penggunaan

Augmented Reality

\subsection{Animasi 3D}

Animasi merupakan grafika yang dimana menampilkan gerakan secara berurutan dengan cepat sehingga objek tersebut terlihat hidup. Dengan perencanaan yang benar dan matang maka alur pergerakan animasi akan menarik untuk di tonton. Jika dalam dunia multimedia animasi merupakan cara menggunakan program pada komputer untuk menghasilkan gerak suatu objek pada layar. Dalam hal ini untuk orang- orang yang sedang membuat animasi dikenal dengan sebutan animator. Animasi 3D objek dapat digerakan ke tiga arah yaituarah ke kanankir (X), atas-bawah (Y) dan depan-belakang (Z). Pada umumnya objek 3D memiliki sub objek berupa elemenelemen pembentuk objek tersebut, yang berupa vertek, edge dan face. Vertek merupakan titik yang terletak pada koordinat $\mathrm{X}, \mathrm{Y}, \mathrm{Z}$. penggabungan dua vertek akan menjadi edge. Tiga vertek dan edgeyang terbentuk dalam bidang permukaan berupa kurva tutup akan menghasilkan Face. Kumpulan dari vertex, edge, dan face akan menjadi sebuah objek utuh yang di sebut dengan Mesh

\section{Analisis Sistem}

\subsection{Usecase Diagram}

Use Case diagram merupakan kontruksi untuk mendeskripsikan hubungan - hubungan yang terjadi antara aktor dengan aktivitas yang terdapat pada aplikasi. Sasaran pemodelan UseCase diantaranya adalah mendefinisikan kebutuhan fungsional dan operasional aplikasi dengan mendefinisikan skenario penggunaan yang disepakati antara pemakai dan pengembang.

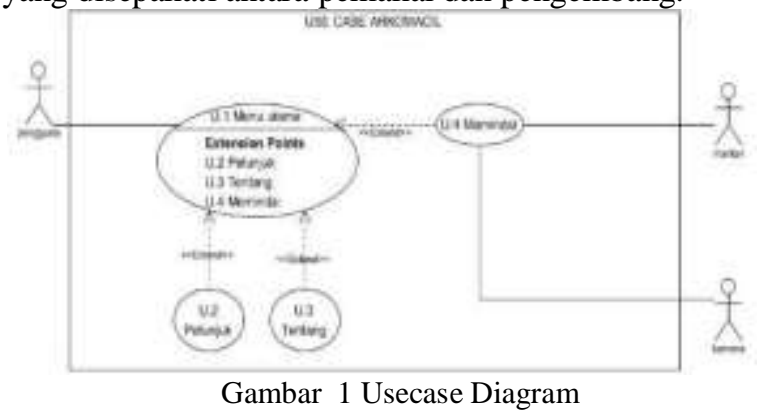

3.2 Activity Diagram

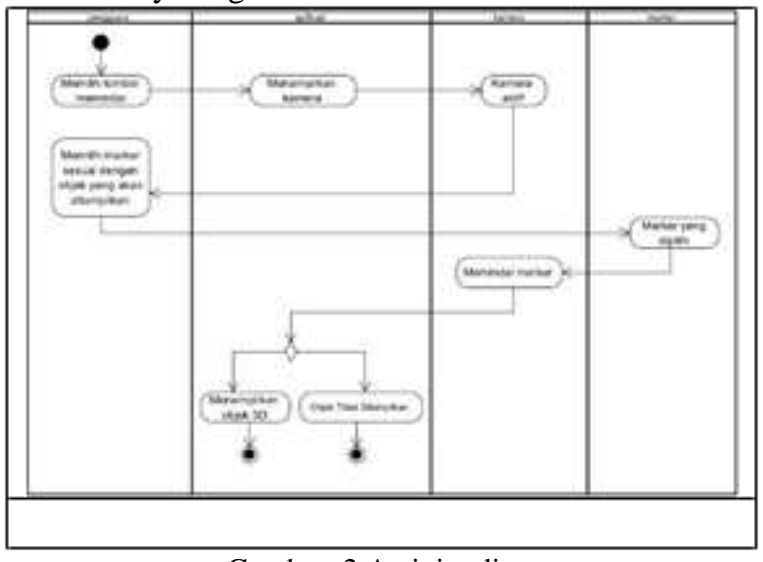

Gambar 2 Activity diagram

Diagram ini menjelaskan bagaimana aktivitas Pengguna/user pada saat berada pada halaman memindai Aplikasi.

\subsection{Storyboard}

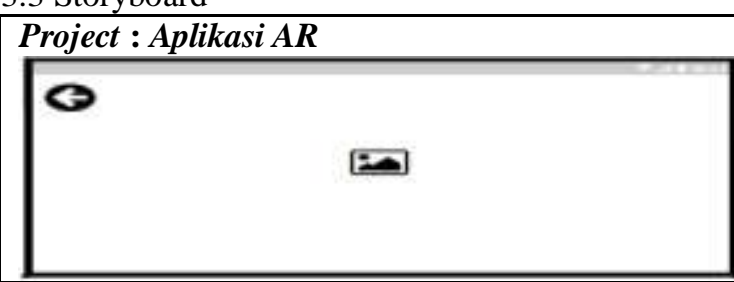

Scene Description :

pada rancangan storyboard kamera, pengguna dapat melakukan aksi seperti memindai marker, memutar suara, dan kembali ke menu utama. Jika pengguna memindai marker, maka aplikasi akan menampilkan objek 3D komponen ac mobil dan mengeluarkan suara dari deskripsi dan estimasi harga, waktu dan perawatan. informasi sesuai dengan objek 3D komponen ac mobil. Dan jika pengguna memilih tombol home, maka aplikasi menampilkan menu utama aplikasi.

\begin{tabular}{|c|c|}
\hline $\begin{array}{l}\text { Link from scene name: } \\
\text { MenuUtama }\end{array}$ & $\begin{array}{l}\text { Link to scene name } \\
\text { : MenuUtama }\end{array}$ \\
\hline \multicolumn{2}{|c|}{ Asset $:$ button, objek 3D komponen ac mobil } \\
\hline $\begin{array}{l}\text { Audio : motorfan.mp3, frec } \\
\text { kondensor.mp3, filteru } \\
\text { relay.mp3, expansi.m } \\
\text { kompressor.mp3, } \\
\text { evaporator.mp3, }\end{array}$ & $\begin{array}{l}\text { mp3, selang.mp3, } \\
\text { ara.mp3, dryer.mp3 } \\
\text { thermostat.mp3 } \\
\text { pressureswitch.mp3 }\end{array}$ \\
\hline
\end{tabular}




\section{Implementasi Sistem}

Tahap implementasi merupakan proses lanjutan dari hasil analisis dan perancangan yang telah dilakukan sebelumnya. Implementasi merupakan proses representasi dari analisis dan perancangan menjadi suatu aplikasi atau pengkodean program dengan bahasa pemrograman tertentu.adapun kebutuhan implementasi yaitu perangkat keras minimal Komputer dengan Processor : Intel Core i3. dan Smartphone Android.dan untuk kebutuhan pernagkat lunak yaitu Unity 3D, Blender, android SDK dan Vuforia SDK

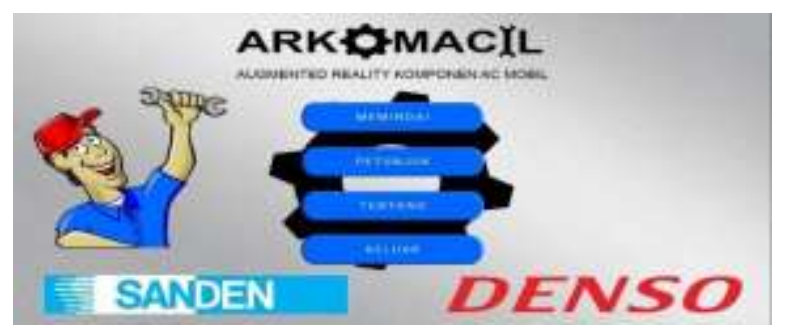

Gambar 3 Antarmuka Menu

Menu utama aplikasi akan muncul setelah aplikasi telah dijalankan atau dibuka oleh pengguna. Pada menu utama akan menampilkan beberapa fungsi tombol yaitu tombol memindai, tombol petunjuk, tombol tentang, tombol keluar.

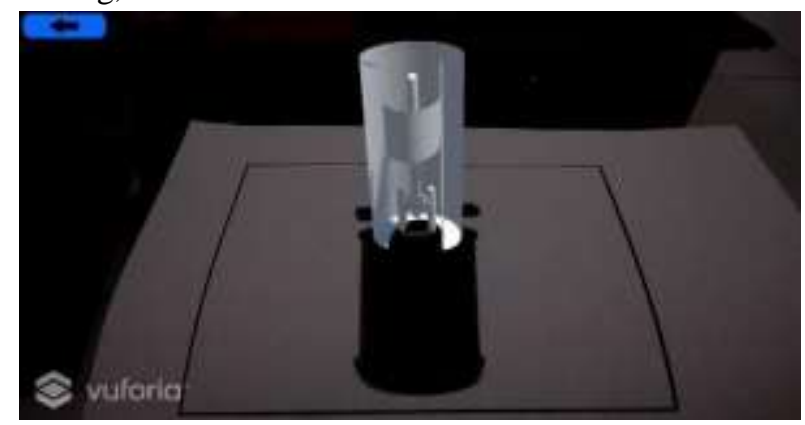

Gambar 4 Antarmuka Kamera

Interface kamera akan muncul setelah pengguna memilih tombol memindai yang terdapat pada menu utama, halaman memindai ini memiliki fungsi yaitu untuk menampilkan objek $3 D$ komponen AC mobil, serta deskripsinya.

\section{Simpulan}

Dari hasil penelitian, perancangan dan implementasi yang telah dilakukan, penulis dapat menyimpulkan sebagai berikut :

a. Dibangunnya sebuah aplikasi pelayanan informasi komponen AC mobil dengan augmented reality berbabasis android.

b. Menerapkan teknologi augmented reality pada komponen-komponen AC mobil berupa animasi objek 3D.

c. Dengan adanya aplikasi ini diharapkan dapat mempermudah dan menambah pengetahuan informasi bagi konsumen.

\section{Daftar Pustaka}

[1]. Binanto, I. (2010). Multimedia Digital Dasar Teori Dan Pengembangannya

[2]. Fowler, 2004. UML Distilled 3th Ed. Panduan Singkat Bahasa Pemodelan Objek Standar. Yogyakarta : Andi

[3]. Fernando, Mario. 2013. "Membuat Aplikasi Augmented Reality Menggunakan Vuforia SDK dan Unity". skripsi.Program Studi Teknik Informatika: Universitas Klabat Manado Ham

[4]. Azuma, R. T., 1997, A Survey of Augmented Reality, Presence : Teleoperators and Virtual Environments $6 \quad$ (4): 355-385. (http://www.cs.unc.edu/ azuma/ARpresence.pdf)

[5]. Andre, Maryuni dan Ridwan. "Mudah Membuat Game Augmented Reality dan Virtual Reality Dengan Unity 3D".2017. Diperoleh 3 Desember 2018, dari (https://s3.amazonaws.com/elexmedia/preview/9786 020400389.pdf) 